\title{
Intra-islet glucagon secretion and action in the regulation of glucose homeostasis
}

\author{
Qinghua Wang ${ }^{1,2,3 *}$, Xinyun Liang ${ }^{1,2}$ and Susanne Wang ${ }^{1}$ \\ 1 Division of Endocrinology and Metabolism, The Keenan Research Centre in the Li Ka Shing Knowledge Institute, St. Michael's Hospital, Toronto, ON, Canada \\ 2 Department of Physiology, University of Toronto, Toronto, ON, Canada \\ ${ }^{3}$ Department of Medicine, University of Toronto, Toronto, ON, Canada
}

Edited by:

Wei-Ping Han, Singapore

Bioimaging Consortium, Singapore

Reviewed by:

Jongrae Kim, University of

Glasgow, UK

Guanglong Jiang, Capital Normal

University, China

Fan Zhang, Mount Sinai School

of Medicine, USA

Wei Zhang, University of

Michigan, USA

${ }^{*}$ Correspondence:

Qinghua Wang, Division of

Endocrinology and Metabolism,

The Keenan Research Centre,

Li Ka Shing Knowledge Institute,

St. Michael's Hospital, 209 Victoria

Street, Room 414, Toronto,

ON M5B 1T8, Canada.

e-mail: qinghua.wang@utoronto.ca
Glucagon, a key hormone in the regulation of glucose homeostasis, acts as a counter-regulatory hormone to insulin by promoting hepatic glucose output. Under normal conditions, insulin and glucagon operate in concert to maintain the glucose level within a narrow physiological range. In diabetes, however, while insulin secretion or action is insufficient, the production and secretion of glucagon are excessive, contributing to the development of diabetic hyperglycemia. Within an islet, intra-islet insulin, in cooperation with intra-islet GABA, suppresses glucagon secretion via direct modulation of $\alpha$-cell intracellular signaling pathways involving Akt activation, GABA receptor phosphorylation and the receptor plasma membrane translocation, while intra-islet glucagon plays an important role in modulating $\beta$-cell function and insulin secretion. Defects in the insulin-glucagon fine-tuning machinery may result in $\beta$-cell glucose incompetence, leading to unsuppressed glucagon secretion and subsequent hyperglycemia, which often occur under extreme conditions of glucose influx or efflux. Therefore, deciphering the precise molecular mechanisms underlying glucagon secretion and action will facilitate our understanding of glucagon physiology, in particular, its role in regulating islet $\beta$-cell function, and hence the mechanisms behind glucose homeostasis.

Keywords: glucagon secretion, insulin secretion, $\beta$-cells, $\alpha$-cells, hepatic glucose production

\section{BACKGROUND}

Glucagon is a 29-amino acid peptide synthesized and released from the pancreatic $\alpha$-cells, where it is produced through the cleavage of proglucagon by prohormone convertase 2 (Rouille et al., 1997; Jiang and Zhang, 2003). Glucagon exerts its biological actions through the activation of glucagon receptors (Gcgr), which is a $G$ protein-coupled receptor found in various parts of the body including the liver, kidney, adipose tissue, brain, and the pancreatic $\beta$-cells (Burcelin et al., 1995). Activation of glucagon receptor, particularly in the liver, is a critical determinant in controlling the rate of gluconeogenesis and glycogenolysis (Unger, 1985; Lefebvre, 1995). The production and secretion of glucagon, which enhance hepatic glucose production, are important mechanisms by which the body prevents hypoglycemia (Unger, 1985; Lefebvre, 1995). In both animals (Myers et al., 1991; Young et al., 1993) and humans (Lins et al., 1983; Freychet et al., 1988; Hvidberg et al., 1994), the administration of exogenous glucagon elevates glucose levels during a fasted or fed state. Therefore, glucagon is an effective therapy for treating severe hypoglycemia in humans (Freychet et al., 1988; Carstens and Andersen, 1994; Haymond and Schreiner, 2001; Kedia, 2011).

Postprandial hyperglycemia stimulates insulin secretion, which acts on the liver to suppress glucose production. Concomitantly, increased blood glucose levels suppress glucagon secretion and reduce its stimulatory effects on hepatic glucose production. During insulin-induced hypoglycemia, glucagon raises blood glucose levels by enhancing glycogenolysis and gluconeogenesis (Bansal and Wang, 2008) to restore normoglycemia (Freychet et al., 1988). The maintenance of normoglycemia relies on the body's response to a change in the insulin-to-glucagon ratio. During a fed state, an increase in the ratio promotes the transport of excess glucose from the blood to tissues in order to prevent postprandial hyperglycemia (Jiang and Zhang, 2003). During a fasted state, a decrease in glucose levels stimulates hepatic glucose output, preventing hypoglycemia (Unger, 1985).

Excessive secretion of glucagon contributes to the development of diabetic hyperglycemia as a consequence of increased hepatic glucose production (Sherwin et al., 1976; Unger, 1978; Barg et al., 2000; Gastaldelli et al., 2000). Preclinical studies demonstrated that chronic glucagon perfusion resulted in hyperglycemia, glomerular abnormalities, and impaired glucose tolerance, which are symptoms of early stage type 2 diabetes (Li et al., 2008). Interestingly, acute infusion of glucagon resulted in sustained hyperglycemia as a consequence of stimulated gluconeogenesis and glycogenolysis in the liver (Gastaldelli et al., 2000; Shah et al., 2000), which, however, occurred only in human diabetic subjects with impaired $\beta$-cell function, but not in non-diabetic subjects (Rizza et al., 1979). Interestingly, in insulin-withdrawn diabetic patients, the glycemic response to hyperglucagonemia is much greater than those in non-diabetic controls (Sherwin et al., 1976), suggesting that in diabetic individuals, abnormalities in the secretion of not only glucagon, but also insulin, along with the alteration of the glucagon-to-insulin ratio, lead 
to hyperglucagonemia (Bansal and Wang, 2008; Unger and Orci, 2010).

Since insulin is a physiological suppressor of glucagon secretion (Bansal and Wang, 2008), relative insufficient insulin production or declined insulin action in type 2 diabetes may reduce intra-islet insulin action on the suppression of glucagon secretion from the $\alpha$-cells (Greenbaum et al., 1991). At the cellular and molecular levels, we have demonstrated that chronic exposure of $\alpha$-cells to high concentrations of glucose and insulin might impose insulin resistance on these cells (Xu et al., 2006). Insulin resistance in $\alpha$-cells may result in concurrently unsuppressed glucagon secretion under insulin-stimulatory conditions (Bansal and Wang, 2008; Yan et al., 2009). Thus, in type 2 diabetes, despite the $\beta$-cells working at maximum capacity to produce and secrete insulin, hyperglucagonemia, and hyperglycemia persist due to insulin resistance in the $\alpha$-cells (Xu et al., 2006).

Hypoglycemia can produce a variety of detrimental complications, and sometimes with fatal outcomes. This is a considerable challenge in insulin therapy as failure of glucagon counterregulation during hypoglycemia is a key factor limiting insulin treatment in patients with diabetes (Bolli, 1998; Cryer et al., 2003). Since the brain relies on glucose as its sole source of energy, profound hypoglycemia can cause permanent neurological damage, leading to functional brain failure, and even brain death (Cryer, 2007). It should be noted that, during exogenous insulin therapy, insulin levels do not decrease when glucose levels fall. Persistent suppression of $\alpha$-cell response may result in defective glucose counterregulation, leading to insulin-induced hypoglycemia, as a consequence of lacking hepatic glucose production under glucagon-stimulated conditions. Iatrogenic hypoglycemia is usually associated with recurrent morbidity in most patients with type 1 diabetes and many with type 2 diabetes (Bolli, 1998; Cryer et al., 2003). Mechanistically, during insulin therapy for type 1 diabetes, the exogenous level of insulin does not decrease in response to the lowering of blood glucose, due to a lack of endogenous glucose-sensing mechanisms (Stutzer et al., 2012). In type 2 diabetes, however, chronic intra-islet hyperinsulinemia may cause $\alpha$-cell resistance (Tsuchiyama et al., 2007). Presumably, under insulin-stimulatory conditions, intraislet insulin action may not be able to efficiently exert suppressive effects on $\alpha$-cell secretion, whereas under glucagon-stimulatory conditions, intra-islet hyperinsulinemia prevents the glucagon response to hypoglycemia (Banarer et al., 2002). Therefore, persistent suppression of glucagon secretion by exogenous insulin impairs the insulin-glucagon fine-tuning system that predominantly maintains glucose homeostasis, and may result in iatrogenic hypoglycemia (Bolli, 1998; Cryer et al., 2003). Particularly, in type 1 diabetes, the lack of insulin-secreting $\beta$-cells diminishes the suppressive effect of endogenous insulin on $\alpha$-cell secretion. As a consequence, the $\alpha$-cells may become more sensitive to exogenous insulin (Bansal and Wang, 2008).

\section{MECHANISMS OF GLUCAGON SECRETION}

Glucose is a predominant factor limiting glucagon secretion (Gerich et al., 1974; Maruyama et al., 1984; Matsuda et al., 2002). The insulin-producing $\beta$-cells and the glucagon-secreting $\alpha$-cells are each featured with a unique set of ion channels
(Kanno et al., 2002; Leung et al., 2005) and are both electrically excitable. The two types of islet cells work in a coordinated manner such that an "on-off" mechanism is established to fine-tune the secretion of insulin and glucagon, and insulin-glucagon levels. Typically, under insulin-stimulatory glucose concentrations, $\beta$ cells are electrically excitatory, and the $\alpha$-cells are electrically silent (Gopel et al., 2000). Within the islets, the regulation of glucagon secretion by glucose and paracrine factors (i.e., the $\beta$-cell secretory products) is mediated by electrical machinery comprising of a variety of ion channels that determine depolarization or hyperpolarization of the $\alpha$-cells (Gopel et al., 2000; Cejvan et al., 2003; Gromada and Rorsman, 2004; Gromada et al., 2004; Yan et al., 2009). The secretion of glucagon requires a full depolarization cascade involving the sequential activation of a number of ion channels. Particularly, the activation of T-type $\mathrm{Ca}^{2+}$ channels depolarizes the cell to an intermediate membrane potential which activates the tetrodotoxin (TTX)-sensitive $\mathrm{Na}^{+}$channels; the influx of $\mathrm{Na}^{+}$ions further depolarizes the $\alpha$-cell, leading to the activation of the $\mathrm{L}$ - or $\mathrm{N}$-type $\mathrm{Ca}^{2+}$ channels and the generation of sustained $\mathrm{Ca}^{2+}$ influx, triggering glucagon granule exocytosis. The hyperpolarization-activated cyclic nucleotidegated $(\mathrm{HCN})$ channels, expressed in the $\alpha$-cells, are presumably involved in initiating the depolarization cascades (Zhang et al., 2008). Maintenance of the ATP-sensitive $\mathrm{K}^{+}\left(\mathrm{K}_{\mathrm{ATP}}\right)$ channel activity in $\alpha$-cells within an appropriate range is critical for allowing the operation of this machinery (Bansal and Wang, 2008). At high glucose concentrations, the closure of the $\mathrm{K}_{\mathrm{ATP}}$ channels, as a consequence of increased intracellular ATP/ADP ratio, depolarizes the $\alpha$-cell membrane potential beyond the narrow window, causing voltage inactivation of the depolarization cascade (Bansal and Wang, 2008). At low glucose concentrations, however, the opening of $\mathrm{K}_{\mathrm{ATP}}$ channels only occurs in a subpopulation of these channels on the $\alpha$-cell and sets the membrane potential to a very negative value, causing the activation of the T-type $\mathrm{Ca}^{2+}$ channels and/or the HCN channels to trigger the subsequent depolarization cascades (Gopel et al., 2000; MacDonald et al., 2007). Importantly, under insulin-stimulatory conditions, insulin appears to be predominant in suppressing glucagon secretion, presumably through either direct interference of the $K_{\text {ATP }}$ channel activity, or the $\alpha$-cell membrane potential-which is exemplified by the insulin-induced activation of the type A receptor for $\gamma$-Aminobutyric acid $\left(\mathrm{GABA}_{\mathrm{A}} \mathrm{R}\right)$ - causing membrane hyperpolarization, or the suppression of the glucagon gene (Bansal and Wang, 2008). Insulin, in cooperation with GABA, suppresses glucagon secretion via direct phosphorylation of $\mathrm{GABA}_{\mathrm{A}} \mathrm{R}$ by protein kinase $\mathrm{B}$ (or Akt), a key molecule in insulin signaling that leads to the translocation of the receptors from intracellular pools to the cell surface and the subsequent membrane hyperpolarization and closure of voltage-dependent calcium channels (Xu et al., 2006).

Intra-islet insulin action has a predominant role in the regulation of glucagon secretion from the $\alpha$-cells. Previous studies suggested that insulin signaling in the $\alpha$-cells plays an important role in glucose-dependent glucagon secretion. In clonal glucagonsecreting $\alpha$-cell lines, the ablation of the insulin receptor using siRNA techniques diminished high-glucose-induced suppression of glucagon secretion (Diao et al., 2005). Furthermore, mice 
lacking $\alpha$-cell specific insulin receptor exhibited elevated glucagon secretion, hyperglucagonemia in the fed state, impaired glucose intolerance and hyperglycemia (Kawamori et al., 2009), indicating the inhibitory effects of intra-islet insulin on glucagon secretion (Bansal and Wang, 2008). The concept that insulin is a physiological suppressor of glucagon secretion is also supported by clinical studies. Studies involving clamp technique, which keeps glucose constant and thus allows for the effects of changes in glucose levels on glucagon secretion to be readily isolated, showed that administrations of insulin suppressed glucagon secretion in healthy humans (Raskin et al., 1975), and patients with type 1 (Raskin et al., 1976) or type 2 diabetes (Greenbaum et al., 1991; Hamaguchi et al., 1991). Similar observations were obtained in diabetic animal models (Braaten et al., 1974; Blazquez et al., 1976). Conversely, blockage of insulin signaling using insulin neutralizing antibody significantly increased glucagon levels in the perfused pancreas of rodents (Maruyama et al., 1984). At the molecular level, insulin can activate intra-islet insulin signaling involving the activation of the PI3K/Akt signaling pathway, which induces subsequent phosphorylation of the $\beta$ subunit of $\mathrm{GABA}_{\mathrm{A}} \mathrm{R}$ and the translocation of receptors from the intra-cellular pool to the plasma membrane. The resulting increase in the $\alpha$-cell surface expression of $\mathrm{GABA}_{\mathrm{A}}$ Rs leads to $\alpha$-cell membrane hyperpolarization and the suppression of glucagon secretion (Xu et al., 2006).

The unique arrangement of islet microvasculature is closely associated with the regulatory role of insulin on glucagon release. It has been previously demonstrated in both human and animal models that $\alpha$-cells are located downstream of $\beta$-cells (Bonner-Weir and Orci, 1982; Stagner et al., 1988; Stagner and Samols, 1992). This permits a direct regulation of glucagon secretion by exposing $\alpha$-cells to a high concentration of insulin. A recent study suggested that the cytoarchitecture of pancreatic islets may differ among species (Cabrera et al., 2006). Although human islets are morphologically different from those of rodent islets, such that the $\beta$-cells are located in the core and $\alpha$-cells in the mantle, the human islets displayed anatomical subdivisions in which the $\beta$-cells are surrounded by $\alpha$-cells (Cabrera et al., 2006; Bosco et al., 2010).

Insulin also inhibits glucagon synthesis by means of repressing the proglucagon gene (Chen et al., 1989; Philippe, 1989), presumably through the activation of the PI3K/Akt signaling pathway (Schinner et al., 2005). Several co-factors and transcription factors, including FoxO1 and Foxa2, are critical in mediating this transcriptional regulation through their direct binding to the proximal promoter region of the proglucagon gene (Philippe et al., 1995; Gauthier et al., 2002; Schinner et al., 2005; McKinnon et al., 2006). The evidence that the ablation of this in trans process diminishes the inhibitory effects of insulin on glucagon biosynthesis and secretion (McKinnon et al., 2006) illustrates the importance of intra-islet insulin in modulating $\alpha$-cell function.

Insulin is not the sole regulator within an islet: glucagon secretion is regulated in autocrine and paracrine fashions, involving a number of islet cell secretory products including GABA produced by the $\beta$-cells (Xu et al., 2006; Braun et al., 2010), glutamate produced by the $\alpha$-cells (Eto et al., 2003; Salehi et al., 2004; Uehara et al., 2004; Cabrera et al., 2006), somatostatin
(Cejvan et al., 2003; Hauge-Evans et al., 2009), and possibly incretins (Gromada and Rorsman, 2004; Marchetti et al., 2012) and ghrelin (Salehi et al., 2004; Zhou et al., 2007). It should be noted that L-glutamate and GLP-1 are known to stimulate insulin secretion; thus, their inhibitory effects on glucagon may be indirect and mediated through insulin actions. Clinical evidence suggests that indirect reciprocal $\beta$-cell-mediated signaling of $\alpha$-cells appears to be predominant over the direct $\alpha$-cell signaling in the regulation of glucagon secretion (Banarer et al., 2002; Gosmanov et al., 2005). This notion is consistent with the physiological relevance underlying glucagon secretion. For instance, under euglycemic basal conditions, $\beta$-cell secretory products tonically restrain $\alpha$-cell glucagon secretion; under $\beta$-cell stimulatory conditions, i.e., after meal ingestion, an increase in $\beta$-cell secretion counteracts the direct $\alpha$-cell stimulation, leading to no change or suppression of glucagon secretion from the $\alpha$-cells (Cooperberg and Cryer, 2009). However, in hypoglycemia, a decrease in $\beta$-cell secretion, in concert with a low $\alpha$-cell glucose concentration, stimulates $\alpha$-cell glucagon secretion (Barg et al., 2000; Bevan, 2001; Banarer et al., 2002; Bancila et al., 2005). This regulatory mechanism is further supported by a recent study indicating that an increase in insulin per se suppresses glucagon secretion and a decrease in insulin per se, in concert with a low glucose concentration, stimulates glucagon secretion in humans (Cooperberg and Cryer, 2010).

Interestingly, insulin coordinates with GABA to suppress $\alpha$-cell secretion via $\alpha$-cell membrane hyperpolarization, which inhibits the exocytotic machinery (Xu et al., 2006). In contrast, when this cooperation occurs in $\beta$-cells, it enhances $\beta$-cell secretion in a fine-tuned range (Bansal et al., 2011). GABA, a non-coding amino acid produced by $\beta$-cells, induces membrane hyperpolarization of $\alpha$-cells (Xu et al., 2006), whereas in the $\beta$-cells, it exerts depolarizing trophic effects (Soltani et al., 2011; Braun et al., 2010). Furthermore, the glutamate released from the $\alpha$-cells can act upon its own cells, although controversial (Uehara et al., 2004), to potentiate (Cabrera et al., 2008) its own secretory ability in an autocrine fashion.

Activation of $\alpha$-cell insulin receptor stimulates $\mathrm{GABA}_{\mathrm{A}} \mathrm{R}$ phosphorylation at the $\beta 3$ subunit, enhancing cell surface expression of the $\mathrm{GABA}_{\mathrm{A}} \mathrm{R}$ and leading to $\alpha$-cell hyperpolarization and subsequent suppression of glucagon secretion (Xu et al., 2006; Bansal and Wang, 2008) (Figure 1). In cultured clonal $\alpha$-cells, $\mathrm{GABA}_{\mathrm{A}} \mathrm{R}$ insertion into the plasma membrane is mediated by insulin signaling involving the activation of the PI3K/Akt signaling pathway. In isolated rat islets, treatment with glucose suppressed glucagon secretion, as a result of enhanced intraislet insulin action on the $\alpha$-cells; insulin signaling blockage in $\alpha$-cells diminishes glucose-induced suppression of glucagon secretion ( $\mathrm{Xu}$ et al., 2006). Therefore, the intra-islet insulinAkt- $\mathrm{GABA}_{\mathrm{A}} \mathrm{R}$ pathway is critical in the regulation of glucagon secretion and maintaining an appropriate insulin-to-glucagon ratio (Xu et al., 2006), which is essential for keeping the blood glucagon within a normal range. Remarkably, in a cellular model of "insulin resistance," where high concentrations of glucose and insulin are exposed to $\alpha$-cells to mimic hyperglycemia and hyperinsulinemia, subsequent applications of insulin fail 


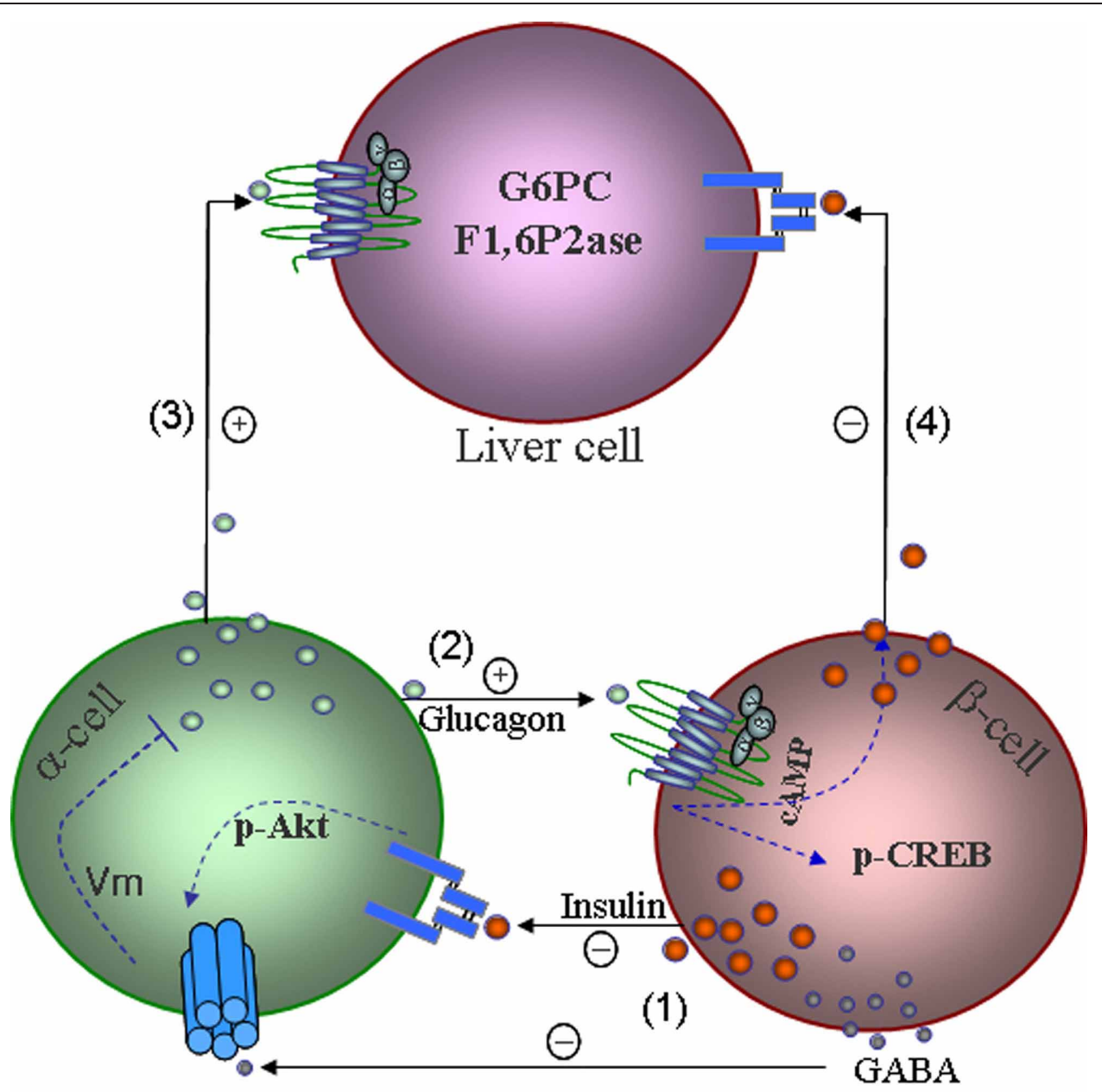

FIGURE 1 | A model shows mechanisms underlying intra-islet hormonal regulation and their impact on liver glucose production. (1) Insulin, incorporation with GABA produced from $\beta$-cells suppresses glucagon secretion via membrane hyperpolarization. (2) Glucagon stimulates glucose-competent $\beta$-cell secretion and increases $\alpha$-cell gene transcription via activation of CREB. (3) Glucagon increases its action in the liver on glucose production under glucagon stimulatory conditions. (4) Insulin increases the suppressive effect of insulin on hepatic glucose production by reducing gluconeogenesis and glycogenolysis. Insulin suppresses glucagon secretion via modulating $K_{\text {ATP }}$ channels and repressing the proglucagon gene, as well as the effects of glucagon and insulin on a variety of organs and tissues are not shown. to increase $\mathrm{GABA}_{\mathrm{A}} \mathrm{R}$ on the cell surface and fail to inhibit glucagon secretion (Xu et al., 2006). These findings provide a molecular mechanism by which glucose-induced suppression of glucagon secretion is mediated by the intra-islet insulin-Akt$\mathrm{GABA}_{\mathrm{A}} \mathrm{R}$ pathway (Figure 1). Defects in this signaling pathway, referred to as $\alpha$-cell insulin resistance (Larsson and Ahren, 2000; $\mathrm{Xu}$ et al., 2006), appear to be a major contributor to hyperglucagonemia and hyperglycemia in type 2 diabetes. Evidence supporting this notion is consistent with clinical observations that $\alpha$-cell insulin resistance exaggerates glucagon responses to stimuli in type 2 diabetic patients (Tsuchiyama et al., 2007). This pathway may also provide a mechanistic explanation, at least in part, for hypoglycemia occurring in insulin-treated type 1 diabetic patients. The $\alpha$-cells of these patients, due to a lack of suppression by endogenous insulin, were rendered hypersensitive to exogenous insulin (Bansal and Wang, 2008).

\section{MECHANISMS OF GLUCAGON ACTION}

The mechanism underlying the regulation of $\alpha$-cell mass expansion and glucagon in response to metabolic changes has not been extensively studied. Observations from a recent study using $\mathrm{db} / \mathrm{db}$ mice demonstrated that $\alpha$-cell mass increased during the development of insulin resistance and hyperinsulinemia (Liu et al., 2011). The expansion of $\alpha$-cell mass under insulin resistant conditions is likely a direct adaptive response to compensate increased demand for insulin in these diabetic mice. This is consistent with the observations that lacking $\alpha$-cell mass expansion and glucagon secretion may cause secondary inability of the $\beta$-cell mass to adapt peripheral insulin resistance in mice under excessive nutrient feeding conditions (Ellingsgaard et al., 2008). Thus it is suggestive that, the intra-islet glucagon plays an important role in the maintenance of $\beta$-cell mass homeostasis and $\beta$-cell competence. This notion is consistent with the findings that treatment of glucagon potentiates glucose-induced 
insulin release in isolated adult human islets (Huypens et al., 2000). The perception is further supported by the evidence that transgenic murine pancreatic $\beta$-cells specifically overexpressing GCGR displayed enhanced glucose-competent insulin secretion, associated with increased $\beta$-cell mass and pancreatic insulin content, rendering the mice partially protected from high-fat diet feeding-induced hyperglycemia and impaired glucose tolerance (Gelling et al., 2009). Conversely, impaired $\beta$-cell function exemplified by declined glucose-induced insulin in isolated islets were profound in $\mathrm{Gcgr}^{-/}$mice lacking glucagon actions (Sorensen et al., 2006). Furthermore, pancreas perfusion studies using specific GCGR antagonists suggested that the intraislet glucagon-induced trophic effects on the $\beta$-cells are mainly through GCGR rather than GLP-1 receptors on islet $\beta$-cells (Kawai et al., 1995), although the gut-derived insulinotropic hormone is recently found to be also produced by the $\alpha$-cells and exerts local actions (Marchetti et al., 2012). The intra-islet trophic effects of glucagon have been further studied using transgenic mice expressing GCGR under control of the muscle specific creatine kinase (Mck) promoter (Maharaj et al., 2012). The Mck/Gcgr mice, which displayed mild hyperglucagonemia (but unchanged circulating GLP-1 levels), are euglycemic under basal conditions but are resistant to streptozotocin-induced $\beta$-cell injury partially due to enhanced intra-islet action of both glucagon and insulin on $\beta$-cell competence (Maharaj et al., 2012).

\section{ROLE OF GLUCAGON IN DIABETES}

Chronic hyperglucagonemia is a major contributor to the development of diabetic hyperglycemia, due to excessive hepatic glucose output either under basal or postprandial conditions (Jiang and Zhang, 2003). Therefore, a strategy involving neutralizing peripheral glucagon actions may be beneficial for hyperglycemia in diabetes. This notion has been tested in recent studies using antibodies antagonizing GCGR, and it has been shown that administration of monoclonal antibodies normalized blood glucose levels in obese diabetic mice and improved glucose tolerance in normal mice and monkeys (Gu et al., 2009; Yan et al., 2009). Various approaches have been reported that are effective in attenuating glucagon actions, including the use of GCGR antagonists and GCGR antisense oligonucleotides (ASOs). Clinical studies showed that GCGR antagonism significantly reduced hyperglucagonemic stimuli-induced hyperglycemia in humans (Petersen and Sullivan, 2001). Consistently, reduction in GCGR expression using ASOs significantly decreased blood glucose, circulating triglyceride, free fatty acids, and improved glucose tolerance by diminishing glucagon actions in type 2 diabetes prone $\mathrm{db} / \mathrm{db}$ mice (Liang et al., 2004). The effects of ablation of glucagon actions on the development of insulin-deficient diabetes have been studied in glucagon receptor knockout mice $\left(\mathrm{Gcgr}^{-/-}\right)$. Despite hyperglucagonemia, as a consequence of pancreatic $\alpha$-cell hyperplasia and excessive glucagon production, $\mathrm{Gcgr}^{-/}$mice are hypoglycemic (Gelling et al., 2003). Interestingly, ablation of the $\beta$-cells using high-dose streptozotocin, though causing severe hyperglycemia and hyperketonemia in the wildtype littermates, did not cause hyperglycemia or laboratory manifestations of diabetes in these knockout mice, indicating that ablating Gcgr prevents insulin-deficient type 1 diabetes in mice (Lee et al.,
2011). The critical role of glucagon in the maintenance of glucose homeostasis had been further illustrated in the $\mathrm{Gcgr}^{-/-}$ mice when adenoviral restoration of hepatic GCGR expression consented to the occurrence of diabetes in these mice after streptozotocin destroyed their $\beta$-cells (Lee et al., 2012), suggesting that hepatic glucagon suppression is a key therapeutic target in diabetes.

Glucagon plays a pivotal role in maintaining functions of various organs and tissues. Although ablation of hepatic glucagon actions can prevent the occurrence of diabetic hyperglycemia and metabolic manifestations following $\beta$-cell destruction (Lee et al., 2011, 2012), complete elimination of glucagon action can produce adverse effects, which are exemplified by the phenotypes of $\mathrm{Gcgr}^{-/}$mice who have increased fetal lethality, defective islet development and impaired glucose competence in the $\beta$-cells (Sorensen et al., 2006; Vuguin et al., 2006). To investigate the effects of attenuating hepatic glucagon actions while enhancing intra-islet glucagon actions, our laboratory has generated Mck/Gcgr mice, a line with muscle-specifically expressing GCGR (Maharaj et al., 2012). The rationale behind this approach is that the ectopic overexpression of GCGR in the skeletal muscle, where little GCGRs are produced endogenously, creates a decoy receptor to neutralize excess circulating glucagon and elevates intra-islet glucagon action as a consequence of $\alpha$-cell compensation to the trapping of glucagon in the muscle in Mck/Gcgr mice (Maharaj et al., 2012). These transgenic mice displayed a significant decrease in hepatic glucose6-phosphatase and fructose-1,6-bisphosphatase mRNA levels, suggesting a reduction in gluconeogenesis and glycogenolysis. Remarkably, the Mck/Gcgr mice are euglycemic and possess higher capability in maintaining glycemic stability, particularly under extreme conditions of glucose influx or efflux exemplified by $\beta$-cell injury (Maharaj et al., 2012) and excessive nutrients feeding (Maharaj and Wang unpublished data). The reduced liver gluconeogenesis, glycogenolysis and elevated intra-islet glucagon action as a consequence of glucagon trapping and $\alpha$-cell compensation, respectively, suggest that neutralizing peripheral glucagon actions, while enhancing intra-islet glucagon actions, may present a useful therapeutic approach for diabetes.

\section{SUMMARY}

Glucose is a primary determinant of glucagon secretion by $\alpha$ cells. Within an islet, glucose-stimulated insulin secretion acts as a potent primary physiological regulator to suppress glucagon secretion through a mechanism involving the activation of the insulin-GABA signaling pathway, modulation of $\mathrm{K}_{\text {ATP }}$ activity and suppression of proglucagon gene expression. The regulation of glucagon secretion is multifaceted, and the process of regulating glucagon secretion involves other factors including the autonomic nervous system, somatostatin, ion channels, GLP-1 and L-glutamate. It should be noted that L-glutamate and GLP-1 are known to stimulate insulin secretion; thus, their inhibitory effects on glucagon may be indirect and mediated through insulin actions. Glucagon plays a pivotal role in protecting the body against hypoglycemia through enhanced hepatic output by stimulating glycogenolysis and gluconeogenesis while inhibiting glycolysis and glycogenesis. Intra-islet paracrine glucagon action 
on modulation of $\beta$-cell function is important in the maintenance of $\beta$-cell glucose competence, particularly under extreme conditions of glucose influx and efflux. Therefore, an approach that suppresses liver glucose production while enhancing intraislet glucagon actions may present a new therapeutic strategy for diabetes.

\section{REFERENCES}

Banarer, S., McGregor, V. P., and Cryer, P. E. (2002). Intraislet hyperinsulinemia prevents the glucagon response to hypoglycemia despite an intact autonomic response. Diabetes 51, 958-965.

Bancila, V., Cens, T., Monnier, D., Chanson, F., Faure, C., Dunant, Y., et al. (2005). Two SUR1-specific histidine residues mandatory for zinc-induced activation of the rat KATP channel. J. Biol. Chem. 280, 8793-8799.

Bansal, P., and Wang, Q. (2008). Insulin as a physiological modulator of glucagon secretion. Am. J. Physiol. Endocrinol. Metab. 295, E751-E761.

Bansal, P., Wang, S., Liu, S., Xiang, Y. Y., Lu, W. Y., and Wang, Q. (2011). GABA coordinates with insulin in regulating secretory function in pancreatic INS-1 beta-cells. PLoS ONE 6:e26225. doi: 10.1371/journal.pone. 0026225

Barg, S., Galvanovskis, J., Gopel, S. O., Rorsman, P., and Eliasson, L. (2000). Tight coupling between electrical activity and exocytosis in mouse glucagon-secreting alphacells. Diabetes 49, 1500-1510.

Bevan, P. (2001). Insulin signalling. J. Cell Sci. 114, 1429-1430.

Blazquez, E., Munoz-Barragan, L., Patton, G. S., Orci, L., Dobbs, R. E., and Unger, R. H. (1976). Gastric A-cell function in insulin-deprived depancreatized dogs. Endocrinology 99, 1182-1188.

Bolli, G. B. (1998). Counterregulatory mechanisms to insulin-induced hypoglycemia in humans: relevance to the problem of intensive treatment of IDDM. J. Pediatr. Endocrinol. Metab. 11(Suppl. 1), 103-115.

Bonner-Weir, S., and Orci, L. (1982). New perspectives on the microvasculature of the islets of Langerhans in the rat. Diabetes 31, 883-889.

Bosco, D., Armanet, M., Morel, P., Niclauss, N., Sgroi, A., Muller, Y. D., et al. (2010). Unique arrangement of alpha- and beta-cells in human islets of Langerhans. Diabetes 59, 1202-1210.

Braaten, J. T., Faloona, G. R., and Unger, R. H. (1974). The effect of insulin on the alpha-cell response to hyperglycemia in long-standing alloxan diabetes. J. Clin. Invest. 53, 1017-1021.

Braun, M., Ramracheya, R., Bengtsson, M., Clark, A., Walker, J. N., Johnson, P. R., et al. (2010). Gammaaminobutyric acid (GABA) is an autocrine excitatory transmitter in human pancreatic beta-cells. Diabetes 59, 1694-1701.

Burcelin, R., Li, J., and Charron, M. J. (1995). Cloning and sequence analysis of the murine glucagon receptor-encoding gene. Gene 164, 305-310.

Cabrera, O., Berman, D. M., Kenyon, N. S., Ricordi, C., Berggren, P. O., and Caicedo, A. (2006). The unique cytoarchitecture of human pancreatic islets has implications for islet cell function. Proc. Natl. Acad. Sci. U.S.A. 103, 2334-2339.

Cabrera, O., Jacques-Silva, M. C., Speier, S., Yang, S. N., Kohler, M., Fachado, A., et al. (2008). Glutamate is a positive autocrine signal for glucagon release. Cell Metab. 7, 545-554.

Carstens, S., and Andersen, I. (1994). [Intranasal glucagon in the treatment of hypoglycemia. A therapeutic possibility in the future]. Ugeskr. Laeger 156, 4339-4342.

Cejvan, K., Coy, D. H., and Efendic, S. (2003). Intra-islet somatostatin regulates glucagon release via type 2 somatostatin receptors in rats. Diabetes 52, 1176-1181.

Chen, L., Komiya, I., Inman, L., O'Neil, J., Appel, M., Alam, T., et al. (1989). Effects of hypoglycemia and prolonged fasting on insulin and glucagon gene expression. Studies with in situ hybridization. J. Clin. Invest. 84, 711-714.

Cooperberg, B. A., and Cryer, P. E. (2009). Beta-cell-mediated signaling predominates over direct alphacell signaling in the regulation of glucagon secretion in humans. Diabetes Care 32, 2275-2280.

Cooperberg, B. A., and Cryer, P. E. lates glucagon secretion in humans. Diabetes 59, 2936-2940.

Cryer, P. E. (2007). Hypoglycemia, functional brain failure, and brain death. J. Clin. Invest. 117, 868-870.

Cryer, P. E., Davis, S. N., and Shamoon, H. (2003). Hypoglycemia in diabetes. Diabetes Care 26, 1902-1912. (2010). Insulin reciprocally regu-

\section{ACKNOWLEDGMENTS}

This study was supported by grants from the Canadian Institute for Health Research (CIHR), Canadian Diabetes Association (CDA), and Juvenile Diabetes Research Foundation (JDRF). Qinghua Wang was supported by the CIHR New Investigator Program.

Diao, J., Asghar, Z., Chan, C. B., and Wheeler, M. B. (2005). Glucoseregulated glucagon secretion requires insulin receptor expression in pancreatic alpha-cells. J. Biol. Chem. 280, 33487-33496.

Ellingsgaard, H., Ehses, J. A., Hammar, E. B., Van, Lommel, L., Quintens, R., Martens, G., et al. (2008). Interleukin-6 regulates pancreatic alpha-cell mass expansion. Proc. Natl. Acad. Sci. U.S.A. 105, 13163-13168.

Eto, K., Yamashita, T., Hirose, K., Tsubamoto, Y., Ainscow, E. K., Rutter, G. A., et al. (2003). Glucose metabolism and glutamate analog acutely alkalinize $\mathrm{pH}$ of insulin secretory vesicles of pancreatic betacells. Am. J. Physiol. Endocrinol. Metab. 285, E262-E271.

Freychet, L., Rizkalla, S. W. Desplanque, N., Basdevant, A., Zirinis, P., Tchobroutsky, G. et al. (1988). Effect of intranasal glucagon on blood glucose levels in healthy subjects and hypoglycaemic patients with insulin-dependent diabetes. Lancet 1, 1364-1366.

Gastaldelli, A., Baldi, S., Pettiti, M. Toschi, E., Camastra, S., Natali, A. et al. (2000). Influence of obesity and type 2 diabetes on gluconeogenesis and glucose output in humans: a quantitative study. Diabetes 49 , 1367-1373.

Gauthier, B. R., Schwitzgebel, V. M., Zaiko, M., Mamin, A., Ritz-Laser, B., and Philippe, J. (2002). Hepatic nuclear factor-3 (HNF-3 or Foxa2) regulates glucagon gene transcription by binding to the G1 and G2 promoter elements. Mol. Endocrinol. 16, 170-183.

Gelling, R. W., Du, X. Q., Dichmann, D. S., Romer, J., Huang, H., Cui, L., et al. (2003). Lower blood glucose, hyperglucagonemia, and pancreatic alpha cell hyperplasia in glucagon receptor knockout mice. Proc. Natl. Acad. Sci. U.S.A. 100, 1438-1443.

Gelling, R. W., Vuguin, P. M., Du, X. Q., Cui, L., Romer, J., Pederson, R. A., et al. (2009). Pancreatic betacell overexpression of the glucagon receptor gene results in enhanced beta-cell function and mass. Am. J. Physiol. Endocrinol. Metab. 297, E695-E707.
Gerich, J. E., Charles, M. A., and Grodsky, G. M. (1974). Characterization of the effects of arginine and glucose on glucagon and insulin release from the perfused rat pancreas. J. Clin. Invest. 54, 833-841.

Gopel, S. O., Kanno, T., Barg, S., Weng, X. G., Gromada, J., and Rorsman, P. (2000). Regulation of glucagon release in mouse -cells by KATP channels and inactivation of TTXsensitive $\mathrm{Na}^{+}$channels. J. Physiol 528, 509-520.

Gosmanov, N. R., Szoke, E., Israelian, Z., Smith, T., Cryer, P. E., Gerich, J. E., et al. (2005). Role of the decrement in intraislet insulin for the glucagon response to hypoglycemia in humans. Diabetes Care 28, 1124-1131.

Greenbaum, C. J., Havel, P. J., Taborsky, G. J. Jr., and Klaff, L. J. (1991) Intra-islet insulin permits glucose to directly suppress pancreatic A cell function. J. Clin. Invest. 88, 767-773.

Gromada, J., Ma, X., Hoy, M., Bokvist, K., Salehi, A., Berggren, P. O., et al. (2004). ATP-sensitive K+ channeldependent regulation of glucagon release and electrical activity by glucose in wild-type and SUR1-/mouse alpha-cells. Diabetes 53 (Suppl. 3), S181-S189.

Gromada, J., and Rorsman, P. (2004). New insights into the regulation of glucagon secretion by glucagon-like peptide-1. Horm. Metab. Res. 36, 822-829.

Gu, W., Yan, H., Winters, K. A., Komorowski, R., Vonderfecht, S. Atangan, L., et al. (2009). Longterm inhibition of the glucagon receptor with a monoclonal antibody in mice causes sustained improvement in glycemic control, with reversible alpha-cell hyperplasia and hyperglucagonemia. J. Pharmacol. Exp. Ther. 331, 871-881.

Hamaguchi, T., Fukushima, H., Uehara, M., Wada, S., Shirotani, T., Kishikawa, H., et al. (1991). Abnormal glucagon response to arginine and its normalization in obese hyperinsulinaemic patients with glucose intolerance: importance of insulin action on pancreatic alpha cells. Diabetologia 34, 801-806. 
Hauge-Evans, A. C., King, A. J., Carmignac, D., Richardson, C. C., Robinson, I. C., Low, M. J., et al. (2009). Somatostatin secreted by islet delta-cells fulfills multiple roles as a paracrine regulator of islet function. Diabetes 58, 403-411.

Haymond, M. W., and Schreiner, B. (2001). Mini-dose glucagon rescue for hypoglycemia in children with type 1 diabetes. Diabetes Care 24, 643-645.

Huypens, P., Ling, Z., Pipeleers, D., and Schuit, F. (2000). Glucagon receptors on human islet cells contribute to glucose competence of insulin release. Diabetologia 43, 1012-1019.

Hvidberg, A., Djurup, R., and Hilsted, J. (1994). Glucose recovery after intranasal glucagon during hypoglycaemia in man. Eur. J. Clin. Pharmacol. 46, 15-17.

Jiang, G., and Zhang, B. B. (2003). Glucagon and regulation of glucose metabolism. Am. J. Physiol. Endocrinol. Metab. 284, E671-E678.

Kanno, T., Gopel, S. O., Rorsman, P., and Wakui, M. (2002). Cellular function in multicellular system for hormone-secretion: electrophysiological aspect of studies on alpha-, beta- and delta-cells of the pancreatic islet. Neurosci. Res. 42, 79-90.

Kawai, K., Yokota, C., Ohashi, S., Watanabe, Y., and Yamashita, K. (1995). Evidence that glucagon stimulates insulin secretion through its own receptor in rats. Diabetologia 38, 274-276.

Kawamori, D., Kurpad, A. J., Hu, J., Liew, C. W., Shih, J. L., Ford, E. L., et al. (2009). Insulin signaling in alpha cells modulates glucagon secretion in vivo. Cell Metab. 9, 350-361.

Kedia, N. (2011). Treatment of severe diabetic hypoglycemia with glucagon: an underutilized therapeutic approach. Diabetes Metab. Syndr. Obes. 4, 337-346.

Larsson, H., and Ahren, B. (2000). Islet dysfunction in insulin resistance involves impaired insulin secretion and increased glucagon secretion in postmenopausal women with impaired glucose tolerance. Diabetes Care 23, 650-657.

Lee, Y., Berglund, E. D., Wang, M. Y., Fu, X., Yu, X., Charron, M. J., et al. (2012). Metabolic manifestations of insulin deficiency do not occur without glucagon action. Proc. Natl. Acad. Sci. U.S.A. 109, 14972-14976.
Lee, Y., Wang, M. Y., Du, X. Q., Charron, M. J., and Unger, R. H. (2011). Glucagon receptor knockout prevents insulin-deficient type 1 diabetes in mice. Diabetes 60, 391-397.

Lefebvre, P. J. (1995). Glucagon and its family revisited. Diabetes Care 18, 715-730.

Leung, Y. M., Ahmed, I., Sheu, L., Tsushima, R. G., Diamant, N. E., Hara, M., et al. (2005). Electrophysiological characterization of pancreatic islet cells in the mouse insulin promotergreen fluorescent protein mouse. Endocrinology 146, 4766-4775.

Li, X. C., Liao, T. D., and Zhuo, J. L. (2008). Long-term hyperglucagonaemia induces early metabolic and renal phenotypes of Type 2 diabetes in mice. Clin. Sci. (Lond.) 114, 591-601.

Liang, Y., Osborne, M. C., Monia, B. P., Bhanot, S., Gaarde, W. A., Reed, C., et al. (2004). Reduction in glucagon receptor expression by an antisense oligonucleotide ameliorates diabetic syndrome in $\mathrm{db} / \mathrm{db}$ mice. Diabetes 53, 410-417.

Lins, P. E., Wajngot, A., Adamson, U., Vranic, M., and Efendic, S. (1983). Minimal increases in glucagon levels enhance glucose production in man with partial hypoinsulinemia. Diabetes 32, 633-636.

Liu, Z., Kim, W., Chen, Z., Shin, Y. K., Carlson, O. D., Fiori, J. L., et al. (2011). Insulin and glucagon regulate pancreatic alpha-cell proliferation. PLoS ONE 6:e16096. doi: 10.1371/journal.pone.0016096

MacDonald, P. E., De Marinis, Y. Z., Ramracheya, R., Salehi, A., Ma, X., Johnson, P. R., et al. (2007). A K ATP channel-dependent pathway within alpha cells regulates glucagon release from both rodent and human islets of Langerhans. PLoS Biol. 5:e143. doi: 10.1371/journal.pbio.0050143

Maharaj, A., Zhu, L., Huang, F., Qiu, H., Li, H., Zhang, C. Y., et al. (2012). Ectopic expression of glucagon receptor in skeletal muscles improves glucose homeostasis in a mouse model of diabetes. Diabetologia 55, 1458-1468.

Marchetti, P., Lupi, R., Bugliani, M., Kirkpatrick, C. L., Sebastiani, G., Grieco, F. A., et al. (2012). A local glucagon-like peptide 1 (GLP-1) system in human pancreatic islets. Diabetologia 55, 3262-3272.

Maruyama, H., Hisatomi, A., Orci, L., Grodsky, G. M., and Unger, R. H. (1984). Insulin within islets is a physiologic glucagon release inhibitor. J. Clin. Invest. 74, 2296-2299.

Matsuda, M., Defronzo, R. A., Glass, L., Consoli, A., Giordano, M., Bressler, P., et al. (2002). Glucagon dose-response curve for hepatic glucose production and glucose disposal in type 2 diabetic patients and normal individuals. Metabolism 51, 1111-1119.

McKinnon, C. M., Ravier, M. A., and Rutter, G. A. (2006). FoxO1 is required for the regulation of preproglucagon gene expression by insulin in pancreatic alphaTC1-9 cells. J. Biol. Chem. 281, 39358-39369.

Myers, S. R., Diamond, M. P., AdkinsMarshall, B. A., Williams, P. E. Stinsen, R., and Cherrington, A. D. (1991). Effects of small changes in glucagon on glucose production during a euglycemic, hyperinsulinemic clamp. Metabolism 40, 66-71.

Petersen, K. F., and Sullivan, J. T. (2001). Effects of a novel glucagon receptor antagonist (Bay 27-9955) on glucagon-stimulated glucose production in humans. Diabetologia 44, 2018-2024.

Philippe, J. (1989). Glucagon gene transcription is negatively regulated by insulin in a hamster islet cell line. J. Clin. Invest. 84, 672-677.

Philippe, J., Morel, C., and CordierBussat, M. (1995). Islet-specific proteins interact with the insulin-response element of the glucagon gene. J. Biol. Chem. 270, 3039-3045.

Raskin, P., Aydin, I., and Unger, R. H. (1976). Effect of insulin on the exaggerated glucagon response to arginine stimulation in diabetes mellitus. Diabetes 25, 227-229.

Raskin, P., Fujita, Y., and Unger, R. H. (1975). Effect of insulin-glucose infusions on plasma glucagon levels in fasting diabetics and nondiabetics. J. Clin. Invest. 56, 1132-1138.

Rizza, R., Verdonk, C., Miles, J., Service, F. J., and Gerich, J. (1979). Effect of intermittent endogenous hyperglucagonemia on glucose homeostasis in normal and diabetic man. J. Clin. Invest. 63, 1119-1123.

Rouille, Y., Kantengwa, S., Irminger, J. C., and Halban, P. A. (1997). Role of the prohormone convertase PC3 in the processing of proglucagon to glucagon-like peptide 1. J. Biol. Chem. 272, 32810-32816.

Salehi, A., Dornonville de la Cour, C., Hakanson, R., and Lundquist, I. (2004). Effects of ghrelin on insulin and glucagon secretion: a study of isolated pancreatic islets and intact mice. Regul. Pept. 118, 143-150.

Schinner, S., Barthel, A., Dellas, C., Grzeskowiak, R., Sharma, S. K., Oetjen, E., et al. (2005). Protein kinase $\mathrm{B}$ activity is sufficient to mimic the effect of insulin on glucagon gene transcription. J. Biol. Chem. 280, 7369-7376.

Shah, P., Vella, A., Basu, A., Basu, R., Schwenk, W. F., and Rizza, R. A. (2000). Lack of suppression of glucagon contributes to postprandial hyperglycemia in subjects with type 2 diabetes mellitus. J. Clin. Endocrinol. Metab. 85, 4053-4059.

Sherwin, R. S., Fisher, M., Hendler, R., and Felig, P. (1976). Hyperglucagonemia and blood glucose regulation in normal, obese and diabetic subjects. N. Engl. J. Med. 294, 455-461.

Soltani, N., Qiu, H., Aleksic, M., Glinka, Y., Zhao, F., Liu, R., et al. (2011). GABA exerts protective and regenerative effects on islet beta cells and reverses diabetes. Proc. Natl. Acad. Sci. U.S.A. 108, 11692-11697.

Sorensen, H., Winzell, M. S., Brand, C. L., Fosgerau, K., Gelling, R. W., Nishimura, E., et al. (2006). Glucagon receptor knockout mice display increased insulin sensitivity and impaired beta-cell function. Diabetes 55, 3463-3469.

Stagner, J. I., and Samols, E. (1992). The vascular order of islet cellular perfusion in the human pancreas. Diabetes 41, 93-97.

Stagner, J. I., Samols, E., and BonnerWeir, S. (1988). beta—alpha—delta pancreatic islet cellular perfusion in dogs. Diabetes 37 , 1715-1721.

Stutzer, I., Esterhazy, D., and Stoffel, M. (2012). The pancreatic beta cell surface proteome. Diabetologia 55, 1877-1889.

Tsuchiyama, N., Takamura, T., Ando, H., Sakurai, M., Shimizu, A., Kato, K., et al. (2007). Possible role of alpha-cell insulin resistance in exaggerated glucagon responses to arginine in type 2 diabetes. Diabetes Care 30, 2583-2587.

Uehara, S., Muroyama, A., Echigo, N., Morimoto, R., Otsuka, M., Yatsushiro, S., et al. (2004). Metabotropic glutamate receptor type 4 is involved in autoinhibitory cascade for glucagon secretion by alpha-cells of islet of Langerhans. Diabetes 53, 998-1006.

Unger, R. H. (1978). Role of glucagon in the pathogenesis of diabetes: the status of the 
controversy. Metab. Clin. Exp. 27, 1691-1709.

Unger, R. H. (1985). Glucagon physiology and pathophysiology in the light of new advances. Diabetologia 28, 574-578.

Unger, R. H., and Orci, L. (2010). Paracrinology of islets and the paracrinopathy of diabetes. Proc. Natl. Acad. Sci. U.S.A. 107, 16009-16012.

Vuguin, P. M., Kedees, M. H., Cui, L., Guz, Y., Gelling, R. W., Nejathaim, M., et al. (2006). Ablation of the glucagon receptor gene increases fetal lethality and produces alterations in islet development and maturation. Endocrinology 147, 3995-4006.

Xu, E., Kumar, M., Zhang, Y., Ju, W., Obata, T., Zhang, N., et al. (2006).
Intra-islet insulin suppresses glucagon release via GABA-GABAA receptor system. Cell Metab. 3, 47-58.

Yan, H., Gu, W., Yang, J., Bi, V., Shen, Y., Lee, E., et al. (2009). Fully human monoclonal antibodies antagonizing the glucagon receptor improve glucose homeostasis in mice and monkeys. J. Pharmacol. Exp. Ther. 329, 102-111.

Young, A. A., Cooper, G. J., Carlo, P., Rink, T. J., and Wang, M. W. (1993). Response to intravenous injections of amylin and glucagon in fasted, fed, and hypoglycemic rats. Am. J. Physiol. 264, E943-E950.

Zhang, Y., Zhang, N., Gyulkhandanyan, A. V., $\mathrm{Xu}$, E., Gaisano, $\mathrm{H}$.
Y., Wheeler, M. B., et al. (2008). Presence of functional hyperpolarisation-activated cyclic nucleotide-gated channels in clonal alpha cell lines and rat islet alpha cells. Diabetologia 51, 2290-2298.

Zhou, H., Zhang, T., Harmon, J. S., Bryan, J., and Robertson, R. P. (2007). Zinc, not insulin, regulates the rat alpha-cell response to hypoglycemia in vivo. Diabetes 56, 1107-1112.

Conflict of Interest Statement: The authors declare that the research was conducted in the absence of any commercial or financial relationships that could be construed as a potential conflict of interest.
Received: 20 November 2012; accepted: 12 December 2012; published online: 03 January 2013.

Citation: Wang Q, Liang $X$ and Wang $S$ (2013) Intra-islet glucagon secretion and action in the regulation of glucose homeostasis. Front. Physio. 3:485. doi: 10.3389/fphys.2012.00485

This article was submitted to Frontiers in Systems Biology, a specialty of Frontiers in Physiology.

Copyright (c) 2013 Wang, Liang and Wang. This is an open-access article distributed under the terms of the Creative Commons Attribution License, which permits use, distribution and reproduction in other forums, provided the original authors and source are credited and subject to any copyright notices concerning any third-party graphics etc. 